\title{
Numerical Model for a Nineteenth-Century Hydrometric Module
}

\author{
Jordi Vives-Costa ${ }^{1}$; José-Juan De-Felipe ${ }^{2}$; and Esteban Pena-Pitarch ${ }^{3}$
}

\begin{abstract}
The Cequia of Manresa is a 26-km open channel constructed in the fourteenth century that conveys water from the Llobregat River to the city of Manresa using an elevation difference of $10.4 \mathrm{~m}$. The channel is still operational today, supplying water for domestic, industrial, and agricultural uses to an overall population of 150,000 people. A hydrometric module was constructed in 1864 to regulate the flow rate in the Cequia to under 1,000 L/s. This module was dismantled in 1959 and is currently nonoperational. This work studied the operation of the module and determined whether it met the objectives for which it was built. The module was modeled numerically. Owing to the lack of experimental measures from the module, the model was validated with an analytical model from the literature, which demonstrated its accuracy. The model was created by applying computational fluid dynamics (CFD) using FLOW-3D software. The results showed that the numerical model reproduced the dynamic behavior of the hydrometric module (transitory), and that the old automated system operated correctly, limiting the flow to the required value. The numerical models can be used as a tool for historical research.
\end{abstract}

Author keywords: Computational fluid dynamics (CFD); Three-dimensional simulation; Sluice gate; Weir.

\section{Introduction}

The Cequia of Manresa captures flow from the Llobregat River in the province of Barcelona (Fig. 1). The diversion is obtained by means of a dam located at the municipality of Balsareny; the Cequia conveys water along a route of more than $26 \mathrm{~km}$ to the city of Manresa, where it is distributed in two slopes. It feeds more than over 800 ha of irrigated land; it is used for domestic and industrial purposes (Latorre 2002).

The channel is considered the most important hydraulic work of the late Middle Ages in Catalonia (Latorre 1995). Its construction began in 1337 and involved the construction of 30 aqueducts to negotiate topographic irregularities and 70 bridges to make way for roads and to divert waters from the rainwater runoff. Similarly, a 321-m-long underground tunnel was excavated to convey water. All these elements constitute exponents of medieval engineering and architecture (Sarret 1906).

Kirchner et al. (2002) argued that hydraulic systems cannot be understood outside their historical framework; to understand why the hydrometric module of the channel was designed, it is necessary to investigate the reasons that led to this decision. At first, the

\footnotetext{
'Professor, Departament d'Enginyeria Minera, Industrial i TIC, Escola Politècnica Superior d'Enginyeria de Manresa, Universitat Politècnica de Catalunya, Av. Bases de Manresa 61-73, Manresa 08242, Spain (corresponding author). Email: jordi.vives@upc.edu. ORCID: https:// orcid.org/0000-0003-3854-775X

${ }^{2}$ Professor, Departament d'Enginyeria Minera, Industrial i TIC, Escola Politècnica Superior d'Enginyeria de Manresa, Universitat Politècnica de Catalunya, Av. Bases de Manresa 61-73, Manresa 08242, Spain. ORCID: https://orcid.org/0000-0002-7758-3967

${ }^{3}$ Professor, Departament d'Enginyeria Mecànica, Escola Politècnica Superior d'Enginyeria de Manresa, Universitat Politècnica de Catalunya, Av. Bases de Manresa 61-73, Manresa 08242, Spain. ORCID: https:// orcid.org/0000-0001-5986-5728
}

Cequia was conceived exclusively for agricultural purposes; however, coinciding with the beginnings of the first industrial revolution, the small waterfalls along its route to the Cardener River became a source of energy to power the machines of an incipient industry. This caused a greater demand for water resources to meet the growing consumption of energy. Soon after, the first conflicts between irrigators and industrialists for the exploitation of canal water occurred (Oliveras 1986). The disputes over the flow rate finally led to the construction of the hydrometric module in 1864, by order of Spanish Queen Isabel II. The objective of the hydrometric module was to limit the flow rate to a maximum of $1,000 \mathrm{~L} / \mathrm{s}$. Despite the construction of the hydrometric module, the controversy over the flow of the Cequia during its operation remained. This paper investigated the operation of the module and determined whether it met the objective of regulating the flow of the channel when it was operational.

The original hydraulic module project was designed by engineer Jaime de Castro, who delivered a memorandum accompanied by sketches on August 10,1863. Figs. 2 and 3 show the original sketches of the project from 1863 . The system consisted of two preparatory relaxation vessels. In the first vessel, the width of the channel ranged from 1.5 to $2.4 \mathrm{~m}$ over a length of $7 \mathrm{~m}$. The water then passed to a different vessel, which was $3.8 \mathrm{~m}$ wide and $13.4 \mathrm{~m}$ long. A weir with a crest length of $3.8 \mathrm{~m}$ and a width of $0.4 \mathrm{~m}$ (central weir) was located near the downstream end of the second vessel, over which, supposedly, only $1,000 \mathrm{~L} / \mathrm{s}$ should pass according to the concession. To achieve this objective, an upstream weir located at the first relaxation vessel with a crest located $0.28 \mathrm{~m}$ above the crest level of the central weir was placed on the left wall, with a constant 30-cm head. The flow discharged from the side weir entered a manhole with a manually adjustable sluice gate. This first manhole was connected with a second manhole, which contained the regulation mechanism that operated by means of a float-operated discharge valve. These manholes and the entire regulator mechanism were protected by a hut. The structure of the hydrometric module is still standing today, with the exception of the automatic mechanism and the central weir, which were removed in the midtwentieth century, when the module fell into disuse. Fig. 4 shows the 


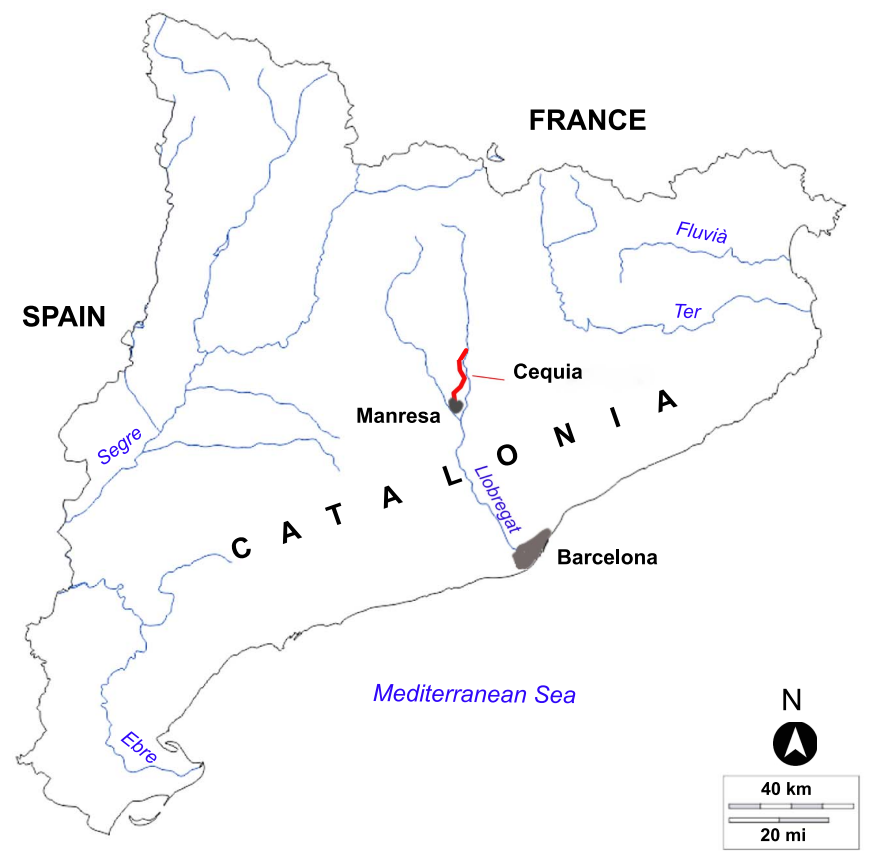

Fig. 1. Location map.

central relaxation vessels, as well as the booth containing the manholes, where the regulation mechanism was housed.

Fig. 5 shows the side weir, which is protected by a grate, and the structure of the two regulation manholes. The first (upstream) manhole has an adjustable sluice gate. The second (downstream) manhole is connected to the first by a $1.15-\mathrm{m}^{2}$ orifice at the bottom. This second manhole contains the float and actuation mechanism of the automatic discharge valve. The space behind the second manhole (Fig. 5) is where the discharge duct with an internal diameter of $0.3 \mathrm{~m}$ was housed.

Computational fluid dynamics (CFD) and the finite-volume method (FVM) have been applied many times for weir flow problems with satisfactory results (Hargreaves et al. 2007; Arvanaghi and Oskuei 2013; Namaee et al. 2014; Zeng et al. 2017). The specific case of lateral wall weirs also has been studied several times (Aydin et al. 2011; Taghavi and Ghodousi 2015; Namaee and Shadpoorian 2016), frequently using FLOW-3D simulation software for general free-surface problems, and specifically for weirs and free nappes (Sarkardeh et al. 2014; Taghavi and Ghodousi 2015).

\section{Method}

\section{Geometries and Computational Domain}

The numeric model of the hydrometric module was constructed on the basis of a reference inertial system in which the $x$-axis was established in the direction of flow, the $y$-axis was established normal to the direction of flow and parallel to the bottom of the channel and, the $z$-axis was established in the direction of the gravity acceleration component. The module was composed, following the flow direction of the fluid stream, in the following sections:

1. The first section is the approach channel, with nominal characteristics equal to those of the channel, i.e., $1.5 \mathrm{~m}$ wide and a wall height of $2 \mathrm{~m}$. For this first section, a length sufficient to stabilize the inlet flow $(6 \mathrm{~m})$ was chosen.

2. The second section (first relaxation chamber), subsequent to the first section, is a section with a $45^{\circ}$ divergence widening to a section $2.4 \mathrm{~m}$ wide and $7 \mathrm{~m}$ long. A side weir is located on the left wall that discharges to the first regulation manhole.

3. The third section (second relaxation chamber) is a continuous channel with a second widening, also at $45^{\circ}$, gives rise to the third section of the module, which is the final part of the regulator. The third section is $3.8 \mathrm{~m}$ wide and $13.4 \mathrm{~m}$ long and houses the weir (central weir) that controls the upstream water level. This weir is just $1.8 \mathrm{~m}$ from the downstream $30^{\circ}$ convergence section, and ends in the fourth section of the system, which is $1.5 \mathrm{~m}$ in length. The physical walls were reproduced in the geometric model as shown in Fig. 6.

4. For simulation purposes, the 1.5-m-wide fourth section was lengthened to $8 \mathrm{~m}$, sufficient to stabilize the flow during simulations.

In total, the model has a length of $34.4 \mathrm{~m}$, a maximum width of $3.8 \mathrm{~m}$ and a wall height of $2 \mathrm{~m}$. The average slope of the channel is 0.0004. The central weir interferes with the main flow that must pass over the weir with a variable head $H$ that is a function of the flow rate. The weir is a rectangular suppressed weir with a crest length of $3.8 \mathrm{~m}$ ( $y$-axis) and a height of $1 \mathrm{~m}$ (z-axis). The weir wall thickness is $0.4 \mathrm{~m}$ ( $x$-axis). Depending on the head on the weir, $H$, a $(H+1)$-m water depth level is obtained in the second and third sections of the module upstream of the weir, which determines the flow of water (if $H$ sufficient) from the side regulating weir.

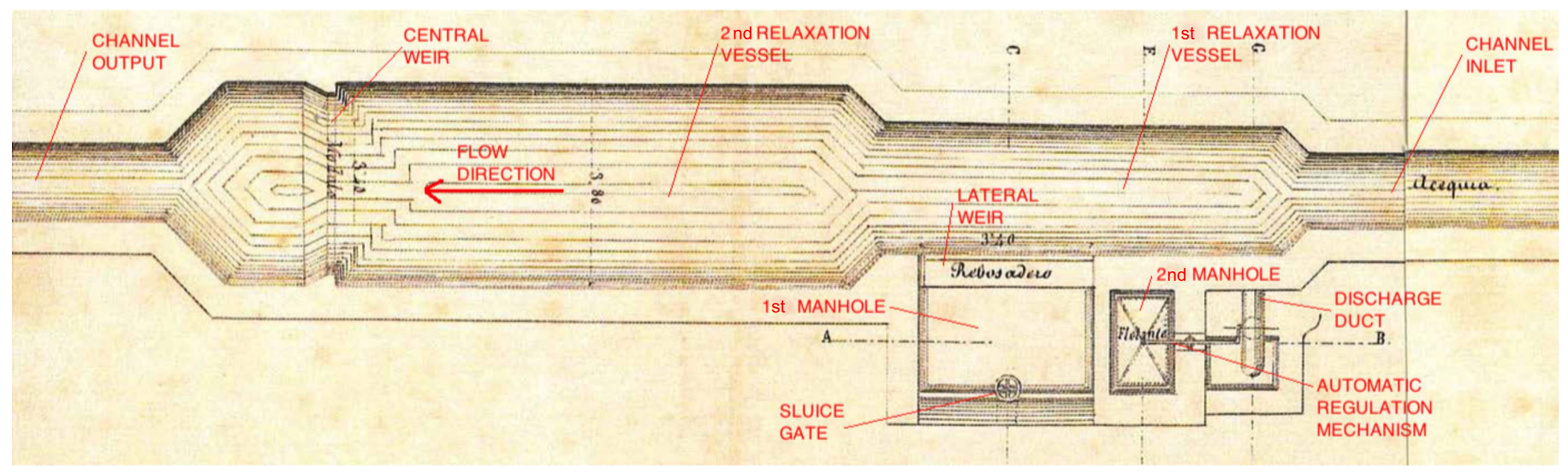

Fig. 2. Plan view of the project of the hydrometric module. (Adapted with permission from J. de Castro, unpublished data, 1863, CDAHCF Archives, Parc de la Sèquia, Manresa, Spain.) 

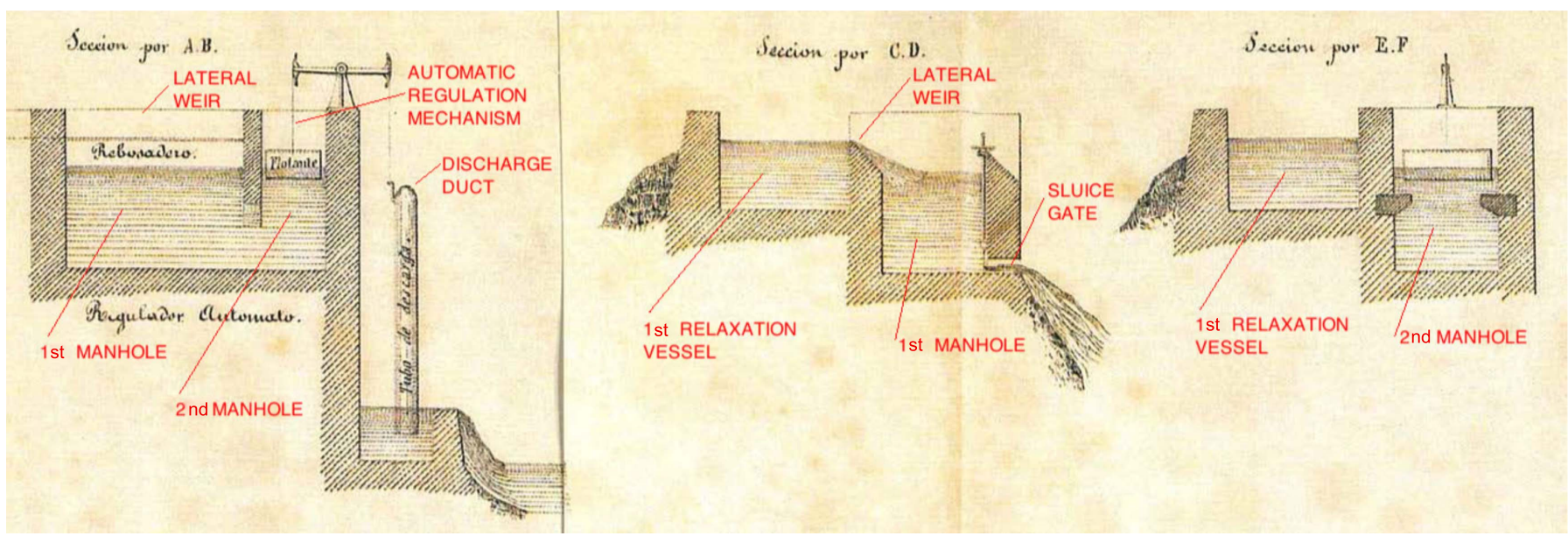

Fig. 3. Cross-section view of the project of the hydrometric module. (Adapted with permission from J. de Castro, unpublished data, 1863, CDAHCF Archives, Parc de la Sèquia, Manresa, Spain.)

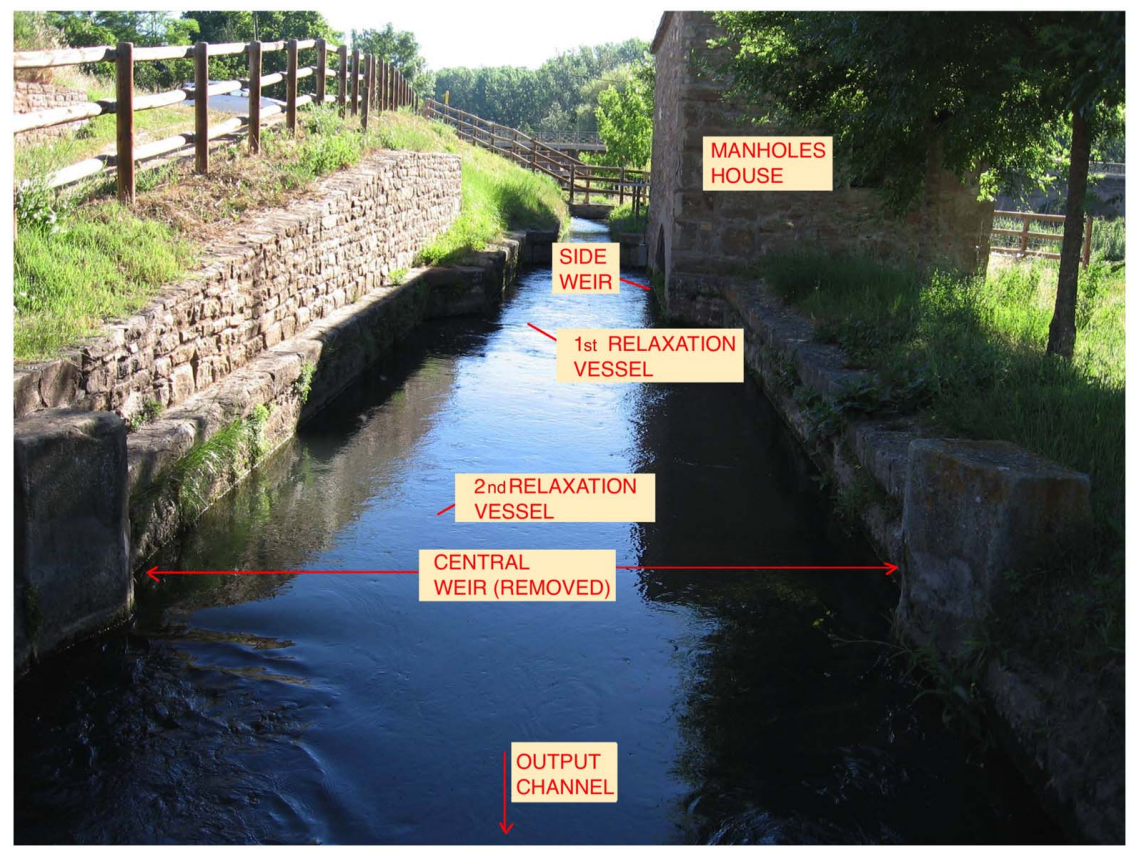

Fig. 4. Hydrometric module structure. (Image by authors.)

The side weir has a height of $1.28 \mathrm{~m}$ above the floor of the channel, which is $0.38 \mathrm{~m}$ higher than the main weir. The first regulation manhole has a rectangular section of $3 \mathrm{~m}$ on the $x$-axis and $2 \mathrm{~m}$ on the $y$-axis, with a height of $3.5 \mathrm{~m}$ ( $z$-axis). This structure is equipped with a 1-m-wide sluice gate that can be adjusted in height to release the excess flow and maintain a relatively constant head that feeds the second manhole. The second manhole is connected to the first through an opening in the common wall. This second manhole has dimensions of $1.4 \mathrm{~m}$ ( $x$-axis) by $2 \mathrm{~m}$ ( $y$-axis) and height of $2.5 \mathrm{~m}$ ( $z$-axis). The second manhole contains the prismatic flotation mechanism, whose dimensions are $1 \mathrm{~m}$ ( $x$-axis) by $0.7 \mathrm{~m}$ (y-axis) and $0.7 \mathrm{~m}$ (z-axis). Fig. 7 shows the right-side view of the model geometry. For the simulation, the original rocker arm float system was replaced with a rigid system of bars that connect the float to the discharge orifice cover (Fig. 8) to simplify simulation while maintaining the same function.

\section{Procedure}

A numerical free-surface CFD model was applied to simulate the flow rate in the hydrometric module. FLOW-3D software version 11.2 was applied to numerically solve the Navier-Stokes equations for solution domains, namely the input and output sections with nominal cross sections of the channel, the relaxation vessels, the central weir, the side weir, the two regulation manholes, a sluice gate, and a circular discharge valve. To estimate turbulence flow, a standard $K$-epsilon model was used. Aydin (2016) analyzed the free surface over a side weir and concluded that the volume of fluid (VOF) method is a good choice for modeling free surface flow with a suitable turbulence model such as $K$-epsilon and is able to simulate flow over a weir (Andersson et al. 2013). Flow conditions in the main channel upstream and downstream of a side weir can have a major influence on the behavior of the flow at the weir itself 


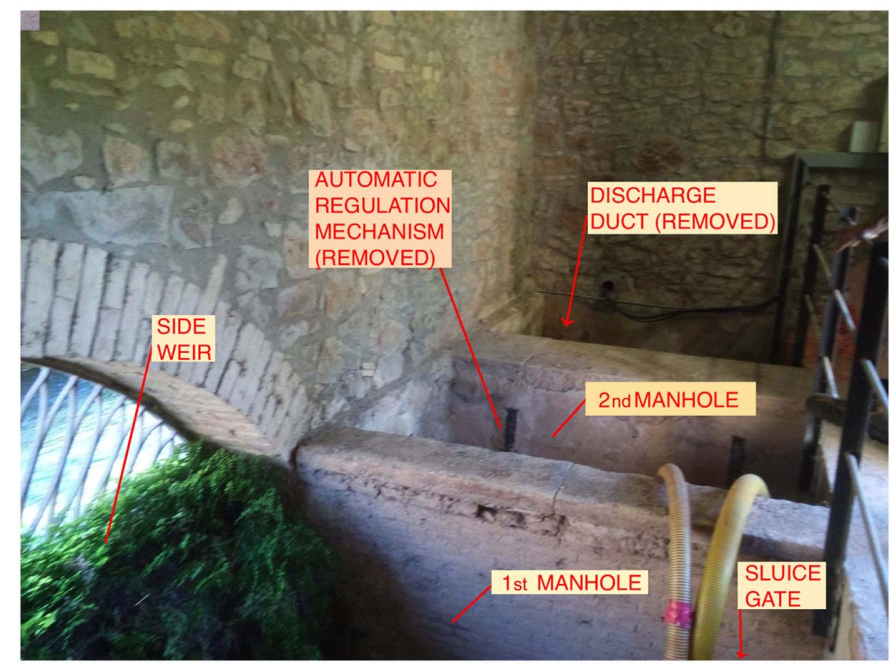

Fig. 5. Inside the hydrometric module building. (Image by authors.)

(Namaee and Shadpoorian 2016). The calculated results were compared, such as pressure, velocities, and output flow rates for different inlet flows.

Six simulations were carried out for inflow rates of 1,000, 1,100, $1,200,1,300,1,400$, and $1,500 \mathrm{~L} / \mathrm{s}$ (Table 1 ). Due to the relatively large physical dimensions of the model and the variable nature of the simulation as a result of the regulation system incorporated in the model, a fairly long simulation time was needed to obtain a suitable solution that demonstrated the model's behavior. A total simulation time of $360 \mathrm{~s}$ was set for each simulation. For an input channel flow of $1,000 \mathrm{~L} / \mathrm{s}$ into an empty channel, a module recharge interval of about $56 \mathrm{~s}$ was observed, so all six flow-rate simulations started at simulation time $t=56 \mathrm{~s}$ and ended at $t=360 \mathrm{~s}$. The average time required to complete each simulation was around $384 \mathrm{~h}$ using an Intel Core i7 7700 s1151 CPU with 16 GB RAM, with a total computational time of $2,304 \mathrm{~h}$ for the six simulations.

\section{Mathematical and Numerical Model}

The filtered incompressible Navier-Stokes equations are solved to study the behavior of the flow. The principle of mass conservation in differential, nonstationary, and three-dimensional form for a given point is given by

$$
\frac{\partial \rho}{\partial t}+\nabla \cdot(\rho \mathbf{v})=0
$$

For these simulations, the fluid can be considered incompressible and of constant density, both in time and in the studied domain, obtaining

$$
\nabla \cdot \mathbf{v}=0
$$

The principle of conservation of momentum, considering incompressible flow is given by

$$
\nabla \cdot(\rho u \mathbf{v})=u \nabla \cdot(\rho \mathbf{v})+(\rho \mathbf{v}) \cdot \nabla u
$$

Considering flow occurs at low velocity and underestimating viscous dissipation, the energy equation expressed in terms of specific enthalpy is

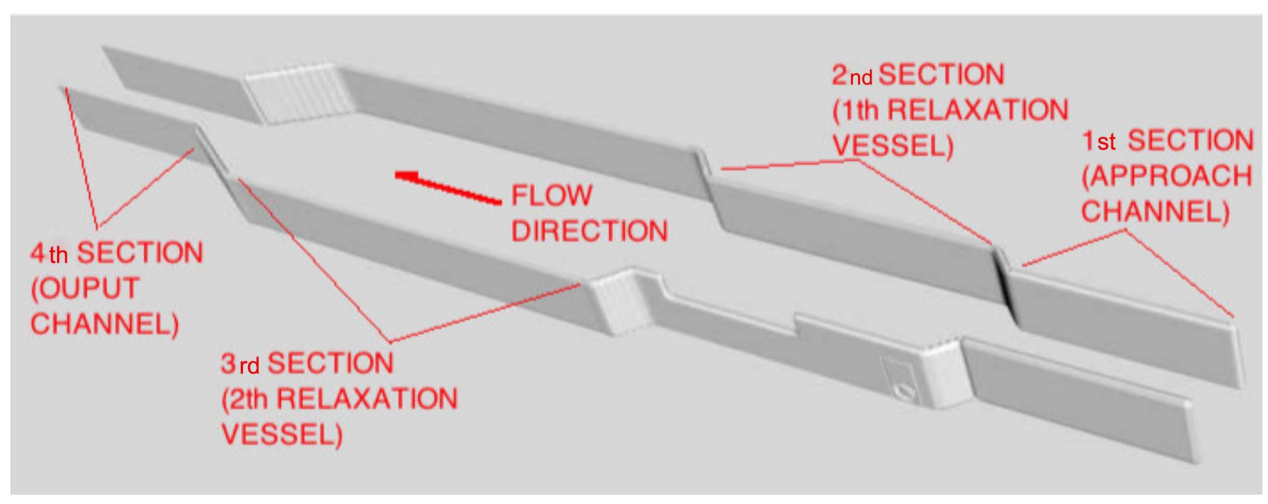

Fig. 6. Definition of the geometry of the walls of the model.

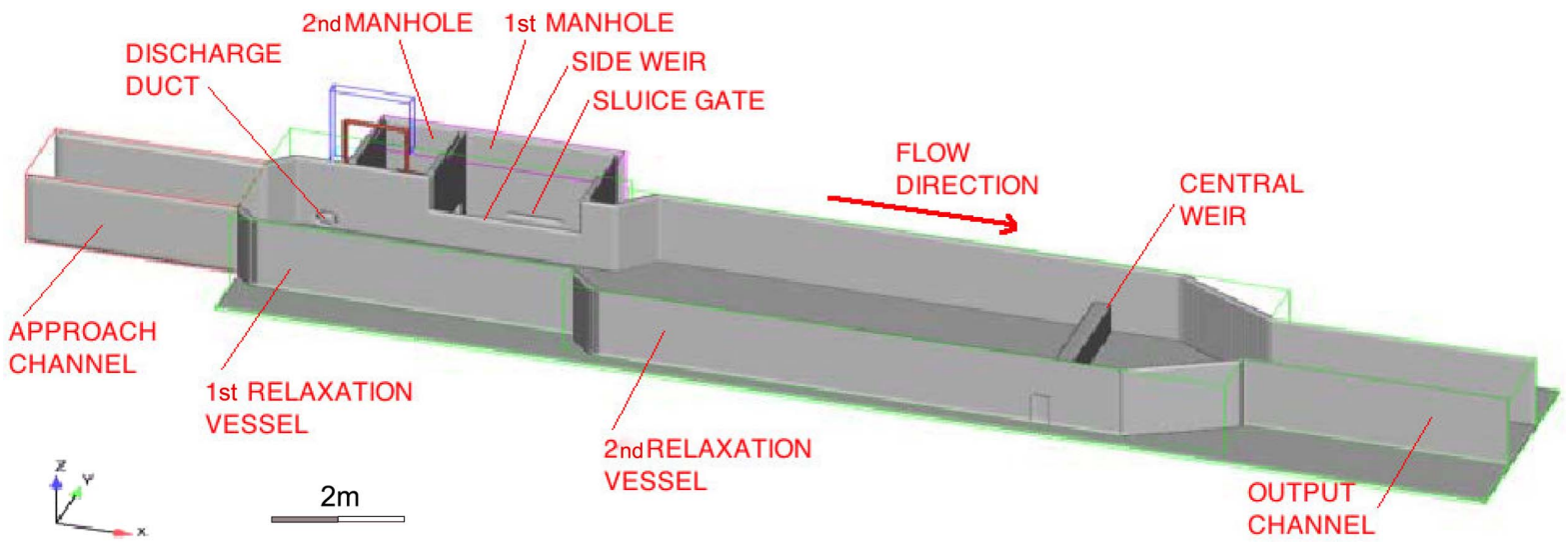

Fig. 7. Right-side view of model geometry. 


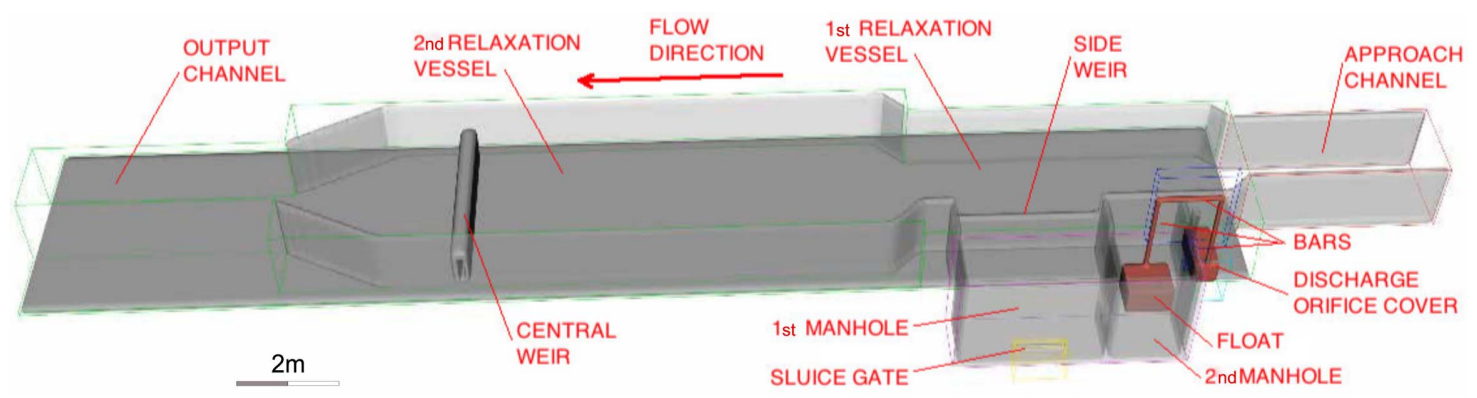

Fig. 8. Left-side view of model geometry.

Table 1. Cases for different inlet flows

\begin{tabular}{lc}
\hline Case & Inlet flow $(\mathrm{L} / \mathrm{s})$ \\
\hline 1 & 1,000 \\
2 & 1,100 \\
3 & 1,200 \\
4 & 1,300 \\
5 & 1,400 \\
6 & 1,500 \\
\hline
\end{tabular}

$$
\frac{\partial(\rho e)}{\partial t}+\nabla \cdot(\rho \mathbf{v} e)=\nabla \cdot(k \nabla T)+S_{h}
$$

The governing equations were discretized by a structured grid arranged using the finite-volume method (Verstappen and Veldman 2003). A second-order conservative scheme was used for spatial discretization. These schemes preserve the symmetrical properties of continuous differential operators and ensure both the conservation of kinetic-energetic equilibrium and model stability (Versteeg and Malalasekera 2007).

\section{Spatial Approximation}

The implicit method was used to solve algebraic equations derived from the system of equations in partial derivatives. Von Neumann stability analysis [Eq. (5)] was used to check the convergence of each mesh block, where $v_{\text {fluid }}$ is the average speed module, $\Delta t$ is the time step, and $\Delta x$ is the cell size

$$
\Delta x \leq\left(2 v_{\text {fluid }} \Delta t\right)^{1 / 2}
$$

Different grades of meshing were used to simulate flow on the model. In order to correctly solve the boundary layer, especially in weir, it was necessary to have a very fine mesh (Ali et al. 2017). A fine mesh was also required around the regulating mechanism, which consisted of the float and the discharge valve actuator, as well as its full potential trajectory. Therefore, a prism layer was appropriate in this area due to the low nonorthogonal corrections required for this type of elements and the relative simplicity in placing this type of control volume near the surface. As flow moves away from the weir, the relative importance of flow structures in force coefficients and velocity profiles decreases, as does mesh resolution.

For the approach channel, the two central relaxation vessels, and the outlet, a mesh with cubic cells of $0.1 \mathrm{~m}$ on each side was arranged. The same mesh size was also used for the first regulation manhole; however, for the second manhole, which houses the float, the mesh was refined to obtain a better characterization of the turbulent phenomena around the float (Stasa, P., Kebo, V. and Kodym, O., Effect of mesh density on the accuracy of the calculation using CFD, presented at 14th SGEM GeoConf. on Informatics, Geoinformatics and Remote Sensing, 2014), with cubic cells of $0.05 \mathrm{~m}$ on each side. The same was done for the outlet volume around the sluice gate of the first manhole and for the volume around the discharge valve of the regulating mechanism. In addition, all the space through which the mechanism can be moved was also rendered with $0.05-\mathrm{m} / \mathrm{side}$ cells. Table 2 summarizes the different meshes in the domain, the size of the cells, and the total number of cells in each region.

\section{Boundary Conditions}

Limiting conditions specify the flow variables or their gradients within the boundaries of the computational flow domain. An upstream boundary can be specified in a channel section where the water level is known for a given flow rate. In this case, the upstream boundary should be at a sufficient distance from the first relaxation vessel to avoid the effect of reflection (Bhajantri et al. 2006). A constant velocity input profile, $u=(U$ ref, 0,0$)$, was imposed to set the limiting conditions. For the model output domain, the relative pressure was set to zero. Symmetrical and no-slip conditions were established for the walls and base of the channel. Relative pressure conditions of zero were imposed for the top of the domain.

\section{Results}

\section{Graphical Analysis}

Graphical analysis was used to observe the behavior of the water velocity gradient in the hydrometric module. Graphical output from

\begin{tabular}{|c|c|c|c|c|}
\hline Mesh block & Domain area & Sections involved & Cell size (m) & Cell units \\
\hline m1 & Central core of canal, relaxation vessels, and output channel & $2,3,4$ & 0.10 & 158,400 \\
\hline $\mathrm{m} 2$ & Approach channel & 1 & 0.10 & 10,080 \\
\hline $\mathrm{m} 3$ & First manhole & 2 (side) & 0.10 & 13,225 \\
\hline $\mathrm{m} 4$ & Sluice gate region & 2 (side) & 0.05 & 2,800 \\
\hline $\mathrm{m} 5$ & Second manhole and discharge valve region & 2 (side) & 0.05 & 16,128 \\
\hline m6 & Region of displacement of regulating mechanism & 2 (side) & 0.05 & 6,720 \\
\hline
\end{tabular}

Table 2. Mesh blocks used in domain 


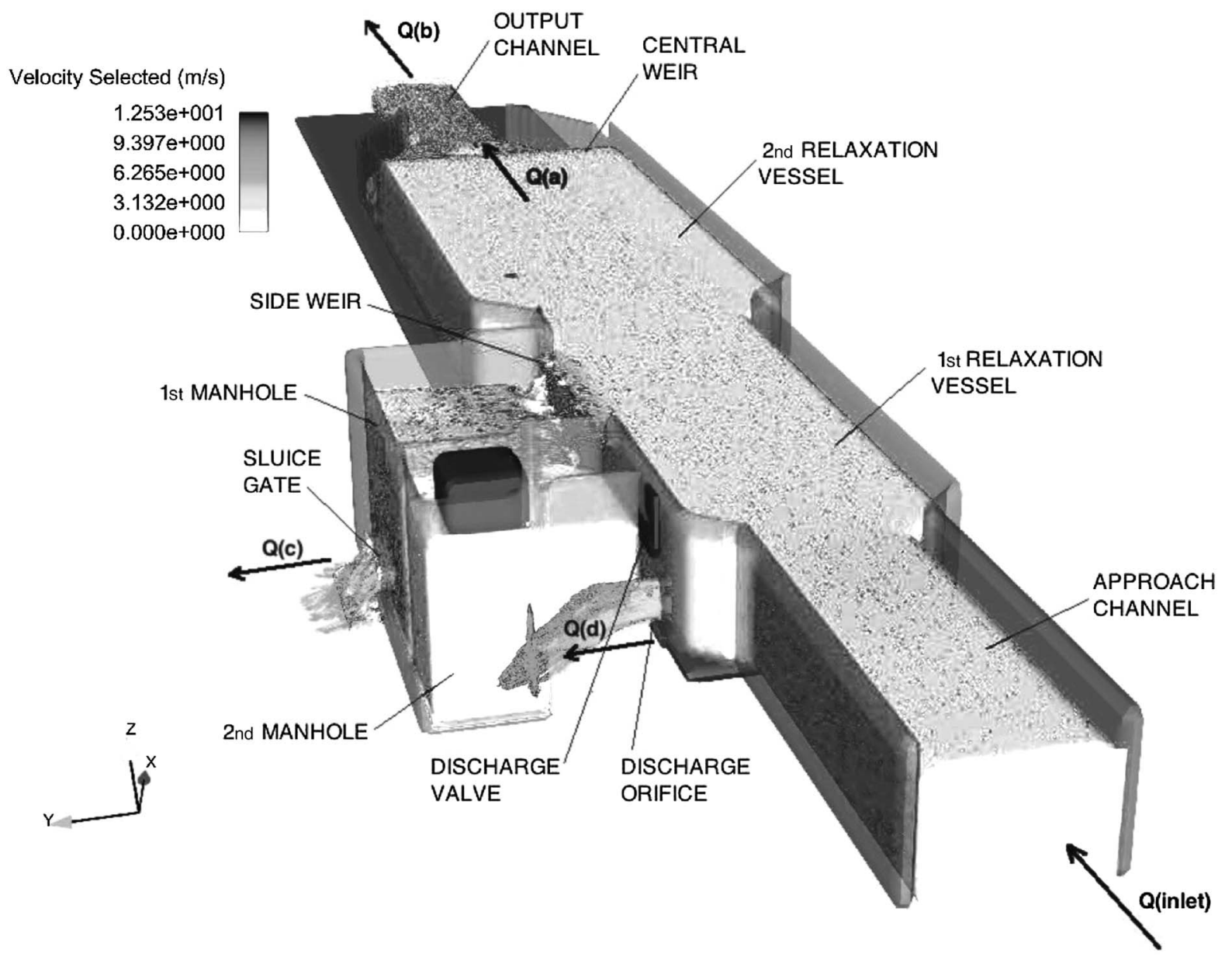

Fig. 9. Rear view at $t=240 \mathrm{~s}$ and $Q=1,300 \mathrm{~L} / \mathrm{s}$.

FLOW-3D software showed the stabilization of the outlet flow downstream of the central weir, as well as the turbulence and hydraulic jump caused by the weir. The same phenomenon was found in the lateral weir, where velocity gradients also were notable.

The water velocity decreased in the two central vessels, and the fluid accelerated in the vicinity of central weir. Turbulence was generated in the region where the hydraulic jump occurred (Babaali et al. 2015). Likewise, the maximum velocity of the water outlet was at the side discharge valve, where the maximum velocity of the entire modeled regulator occurred, whereas the velocity was lowest at the exit of the sluice gate located at the first regulation manhole. Fig. 9 shows the hydrometric module rear view at $t=$ $240 \mathrm{~s}$ with an input flow rate of $1,300 \mathrm{~L} / \mathrm{s}$, and shows the outlet water jet issuing from the discharge valve when it is activated by the ascent of the float in the control box.

\section{Numerical Analysis}

Output flows were simulated for (1) the weir, (2) the downstream boundary of the module, (2) the sluice gate of the first manhole, and (4) the discharge valve of the regulating mechanism. The simulated output flows were variable over time and it was necessary to extend the simulation time to obtain model behavior under steady-state flow conditions. Results obtained for the six cases in Table 1 are shown in Fig. 10, detailing the behavior of the module for different inlet flows. Table 2 lists the mesh blocks used in the domain. Table 3 lists the sections at which flow rates were measured.
Fig. 10 shows the results achieved in the six cases studied. For Case 1, with an input flow rate to the hydrometric module of $1,000 \mathrm{~L} / \mathrm{s}$, the convergence of the flow on the central weir (section a) was obtained from $t=80 \mathrm{~s}$, with a value of around $740 \mathrm{~L} / \mathrm{s}$. For the output flow in the final section of the module (section $\mathrm{b}$ ), after the hydraulic jump, there was a logical delay, $8 \mathrm{~s}$, with respect to the flow on the weir. In addition, this output flow rate was very fluctuating and did not completely stabilize over the entire simulation range. This behavior is explained by the oscillating character of the hydraulic jump between these two sections. This induced very turbulent alterations in its proximity and caused great variations of the free surface of the flow, as well as of its depth and velocities. On the other hand, the discharge flow through the sluice gate of the first manhole (section c) was also variable because the flow that enters the manhole comes from the lateral weir and causes a high level of turbulence during its fall into the manhole. A conclusion of the simulation for the input flow rate of $1,000 \mathrm{~L} / \mathrm{s}$ is that the regulation mechanism is not activated throughout the entire simulation range, and consequently the output flow rate through the control section (d), which corresponds to the discharge valve, is zero.

For Case 2, for an input flow of 1,100 L/s the flow on the weir (section a) stabilized from $t=91 \mathrm{~s}$ with a value of around $771 \mathrm{~L} / \mathrm{s}$ [Fig. 10(b)]. For the control section (b), which is the final output section, the flow had an oscillating behavior; however, the dispersion was smaller than that in Case 1. The flow rate through the sluice gate (section c), was also very variable, similar to that 

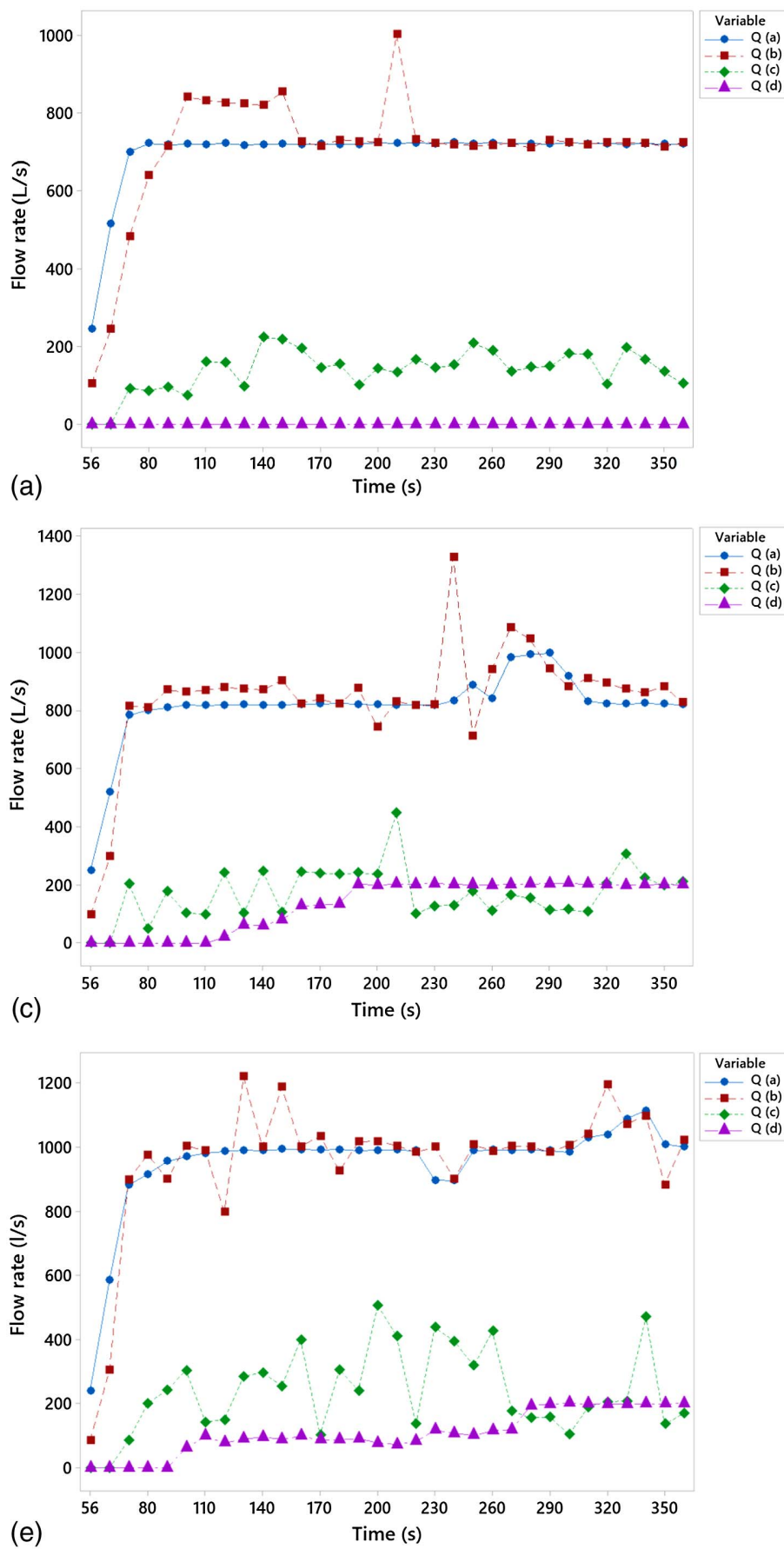
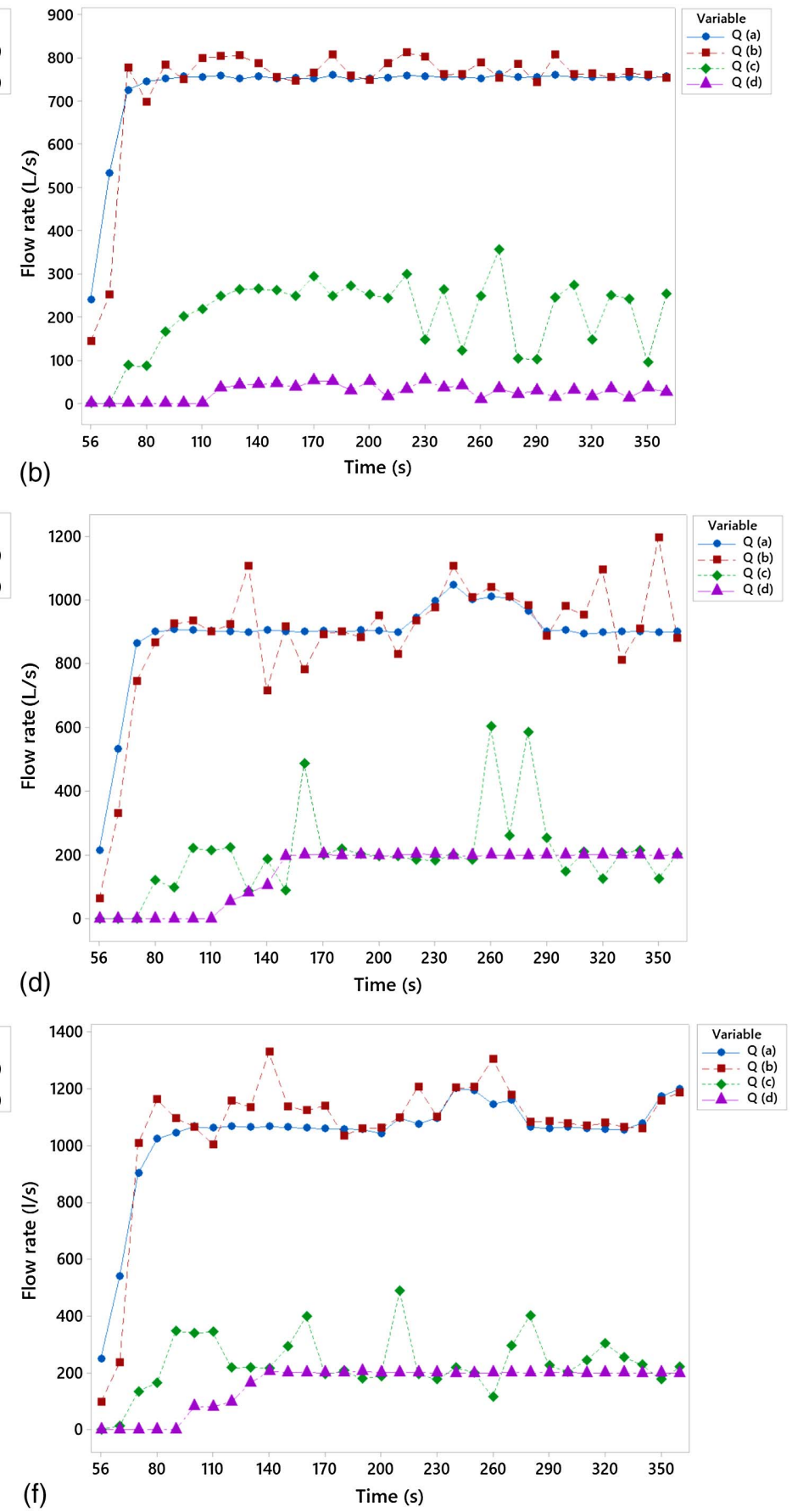

(f)

Fig. 10. Balance of output flows for different input flows: (a) Case 1; (b) Case 2; (c) Case 3; (d) Case 4; (e) Case 5; and (f) Case 6.
Table 3. Measured flow rates through sections

\begin{tabular}{lcc}
\hline Measured flow rate & Section & Mesh involved \\
\hline$Q(a)$ & Central weir & $\mathrm{m} 1$ \\
$Q(b)$ & Output channel & $\mathrm{m} 1$ \\
$Q(c)$ & Sluice gate & $\mathrm{m} 4$ \\
$Q(d)$ & Discharge valve & $\mathrm{m} 5$ \\
\hline
\end{tabular}

obtained in Case 1; however, the behavior was more stable from $t=135 \mathrm{~s}$. The automatic regulation mechanism was actuated from $t=125 \mathrm{~s}$; the flow rate across the control section (d) was zero from $t=0$ to $t=125 \mathrm{~s}$, and from this point onward ranged between $Q=0$ and $Q=100 \mathrm{~L} / \mathrm{s}$, depending on the position of the gauge inside the control manhole. In this case, the mechanism worked perfectly in accordance with the concept and did not reach its limit, which was around $Q=200 \mathrm{~L} / \mathrm{s}$, as was checked subsequently in Simulations 3, 4, 5, and 6.

Case study 3, which corresponded to a flow rate of $1,200 \mathrm{~L} / \mathrm{s}$, showed the maximum opening of the discharge valve of the automatic regulating system for the first time; this occurred from $t=190 \mathrm{~s}$. The discharge valve started to open partially from $t=$ $120 \mathrm{~s}$ and maintained this regulation with partial openings from this time to $t=190 \mathrm{~s}$, after which time it remained fully open until the end of the simulation. From $t=190 \mathrm{~s}$ onward the flow rate through the discharge valve (section d) remained constant at 


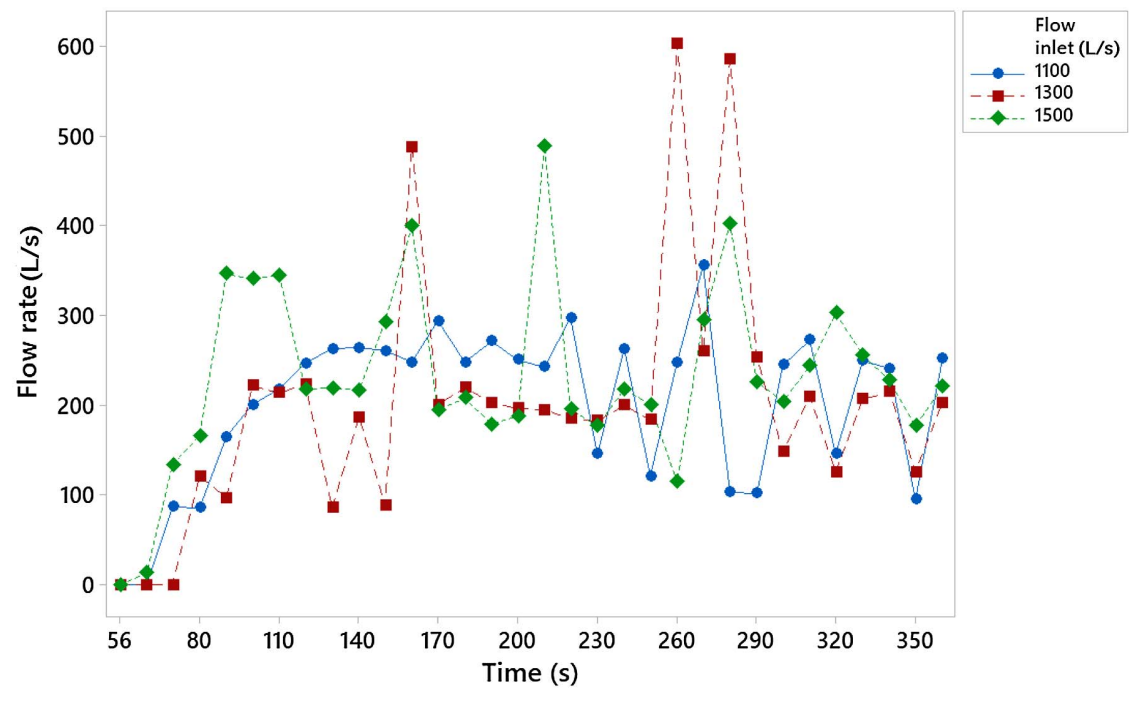

Fig. 11. Flow rate at the outlet sluice gate (section c).

$200 \mathrm{~L} / \mathrm{s}$. Outlet flow on the weir, $Q(a)$, was around $800 \mathrm{~L} / \mathrm{s}$ at a stable rate between $t=80$ and $t=242 \mathrm{~s}$. Between $t=242$ and $t=315 \mathrm{~s}$, the flow on the weir increased to $1,000 \mathrm{~L} / \mathrm{s}$, and stabilized again at $803 \mathrm{~L} / \mathrm{s}$ from $t=315 \mathrm{~s}$ to the end of the simulation interval, $t=360 \mathrm{~s}$. The same phenomenon also occurred in Simulations 4, 5, and 6. In all these cases, the discharge valve opened completely. The maximum flow peaks over the weir were induced after full opening of the discharge valve, probably because of the suction that altered the normal flow over the weir downstream at some point.

The regulated flow rate crossing over the weir (section a) was around $906 \mathrm{~L} / \mathrm{s}$ for Case 4 . Flow behavior on the weir was very stable from $t=90 \mathrm{~s}$. However, the point flow varied between $t=$ 210 and $t=277 \mathrm{~s}$, which resulted in a maximum of $1,050 \mathrm{~L} / \mathrm{s}$ to restore stability up to $t=360 \mathrm{~s}$.

For an input flow rate of 1,400 L/s (Case 5) the regulated flow rate crossing section (a), above the weir, was $981 \mathrm{~L} / \mathrm{s}$, and remains very stable except for a punctual rebound in which the flow rate was a maximum of $1,115 \mathrm{~L} / \mathrm{s}$. With the regulation system operated by the float in the manhole float, it started operating from $t=85 \mathrm{~s}$ in a partial opening mode, with an average flow rate of around $110 \mathrm{~L} / \mathrm{s}$ for section (d) until $t=273 \mathrm{~s}$. From that time onward, the discharge valve opened completely and facilitated discharge of $200 \mathrm{~L} / \mathrm{s}$ until the end of the simulation.

The last case studied (Case 6), was obtained for an input flow of $1,500 \mathrm{~L} / \mathrm{s}$. Outcomes showed that the regulated flow was above the limit value set by the administrative concession. The flow rate above the weir (section a) was $1,070 \mathrm{~L} / \mathrm{s}$, which was slightly higher than the target flow rate, i.e., $7 \%$ higher than the target value of the regulation, $1,000 \mathrm{~L} / \mathrm{s}$, for the concession. This regulated flow rate was $71.3 \%$ of the input flow; in other words, the flow disregarded by the module that was returned to the river in this situation was about $28.7 \%$ of the flow rate absorbed by capturing the irrigation ditch. The value of the flow rate across section (b), at the outlet of the hydrometric module, was very stable with respect to the previous cases, probably due to the fact that when there is a greater depth of water in the channel, fluctuations of free surface caused by the hydraulic jump are relatively minor. The automatic regulation mechanism started to operate at $t=80 \mathrm{~s}$; it operated in partial mode until $t=140 \mathrm{~s}$, after which it remained at maximum speed, with the discharge valve fully open, until the end of the simulation, with an average flow in section (d) of $200 \mathrm{~L} / \mathrm{s}$.
Fig. 11 compares the output flow rate results in section (a), the sluice gate, obtained for Cases 2, 4, and 6, i.e., for inlet flow rates $1,100,1,300$, and $1,500 \mathrm{~L} / \mathrm{s}$. The values of the waste flow had great variability, from a minimum of $130 \mathrm{~L} / \mathrm{s}$ to a maximum of $400 \mathrm{~L} / \mathrm{s}$. Case 1 , corresponding to a flow rate of $1,000 \mathrm{~L} / \mathrm{s}$, is not represented in Fig. 11 because this flow rate did not drive the automatic regulation mechanism (Fig. 10). Results of Cases 3 and 5 are not represented in order to make Fig. 11 easier to read.

Fig. 12 compares the discharge valve flow rates (section d) for Models 2, 3, 4, 5, and 6, which correspond to inlet flow rates from 1,100 to $1,500 \mathrm{~L} / \mathrm{s}$ in $100-\mathrm{L} / \mathrm{s}$ steps. The mechanism started partial operation between $t=80$ and $t=120 \mathrm{~s}$ depending on the different inlet flow rates, so it opens earlier, when the flow is greater. The only case in which the regulation mechanism operated partially for the entire simulation was Case 2 for $Q=1,100 \mathrm{~L} / \mathrm{s}$, whereas for the rest of cases, the operation was partial opening to full opening from $t=130$ to $t=280 \mathrm{~s}$, depending on the input flow rate. When the automatic regulation system operated in total mode, a discharge capacity of $200 \mathrm{~L} / \mathrm{s}$ was achieved regardless of the input flow rate.

Fig. 13 compares of the flow values obtained on the weir (section a) for different inlet flows between 1,100 and $1,500 \mathrm{~L} / \mathrm{s}$ in intervals of $100 \mathrm{~L} / \mathrm{s}$. The values obtained were below the maximum limit of $1,000 \mathrm{~L} / \mathrm{s}$ established by the administrative concession for Cases 1, 2, 3, 4, and 5. However, for an input flow of $1,500 \mathrm{~L} / \mathrm{s}$ (Case 6), there was a small surplus of $7 \%$. This percentage is very small in relation to the input flow rate, which is $50 \%$ higher than the flow to be regulated. Oscillations appeared as peak flow rates; however, the discharge valve is fully opened after a certain interval of time, then fluctuations stabilized quickly (Fig. 13).

\section{Validation}

Validation was based on the correspondence of the values obtained analytically in advance of the numerical model. The analytical model described a physical phenomenon from the equations recognized by the scientific literature. Numerical results obtained for the discharge pipe outlet flow rate (section d) were compared with the calculations obtained analytically for different heads 


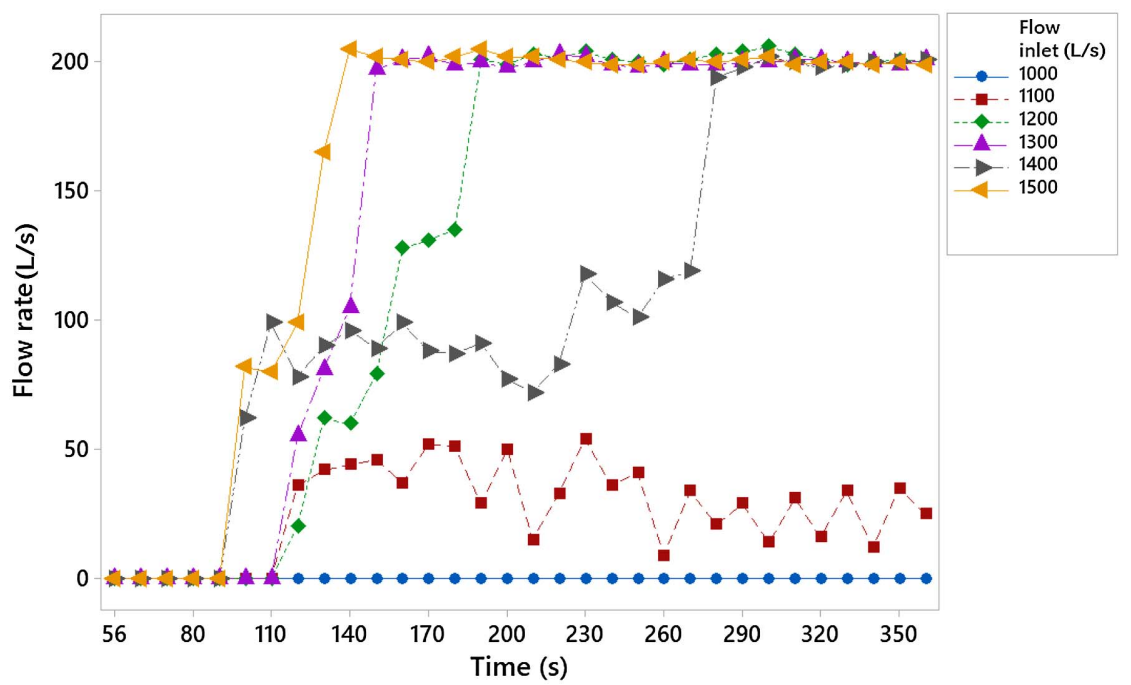

Fig. 12. Flow rate at the discharge valve (section d).

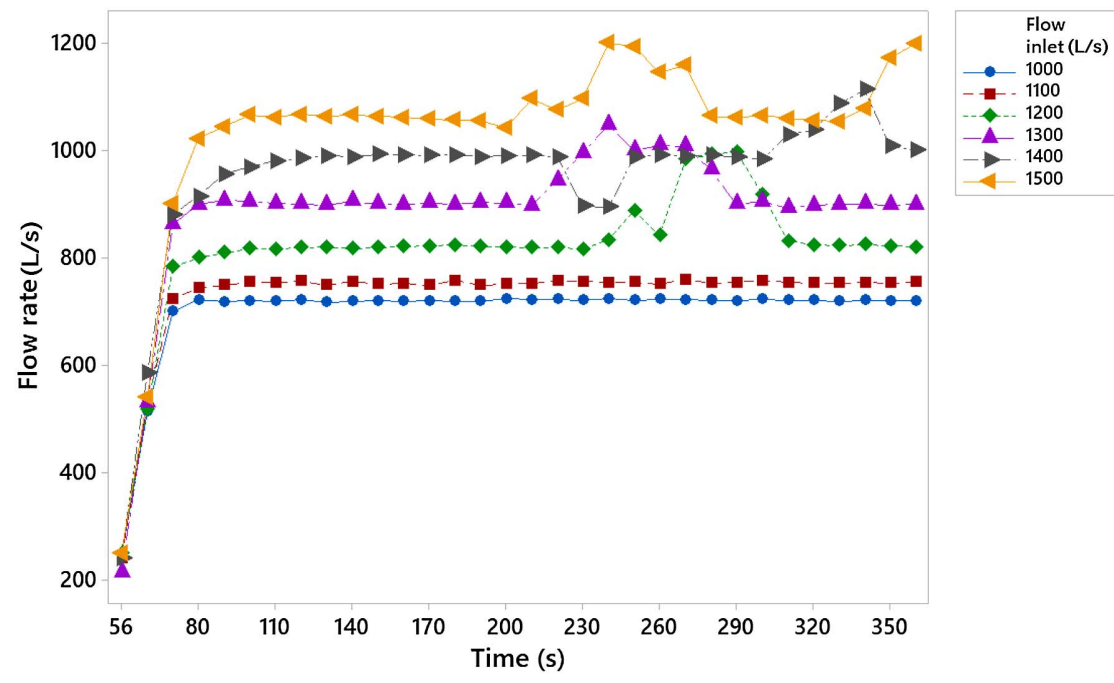

Fig. 13. Flow rate at the central weir (section a).

$$
Q_{(d)}=k_{d} A_{h}(2 g H)^{1 / 2}
$$

The Torricelli equation [Eq. (6)] was used to determine the outlet flow, $Q$, through the discharge valve from the head above it, $H$; the orifice area, $S_{h}$; and a nondimensional discharge coefficient, $K_{d}$, that depends on the geometry of the orifice (Franchini and Lanza 2013; Blasone et al. 2015). The discharge coefficient for a thin-walled circular orifice has been estimated at 0.6 (White 1999).

Discharge over the central weir (section a) was determined from

$$
Q_{(a)}=\frac{2}{3} C_{d}(2 g)^{1 / 2} b h^{3 / 2}
$$

where $h=$ head on the crest; $b=$ weir width; and $C_{d}=$ dimensionless discharge coefficient which depends on the geometry of the weir (Aydin et al. 2011; Pandeyp et al. 2016; Arvanaghi and Oskuei 2013; Wu and Rajaratnam 2015). The discharge coefficient for a thin-walled rectangular weir has been estimated at 0.6 (Arvanaghi and Oskuei 2013; Turalina et al. 2015; Lin et al. 2002).
Table 4 compares the values obtained with the numerical simulation and those obtained analytically from Eq. (1) for section (d), corresponding to the discharge valve. Results for Cases 1 and 2 were not be relevant. For the first case the automatic mechanism was not activated and therefore the flow rate was zero, even though there was an average head of $0.2 \mathrm{~m}$; Case 2 was not taken into

Table 4. Flow rates obtained analytically versus model-derived flow rates in section (d) (discharge valve)

\begin{tabular}{lccccc}
\hline Case & $\begin{array}{c}\text { Input flow } \\
\text { rate }(\mathrm{L} / \mathrm{s})\end{array}$ & $\begin{array}{c}Q \text { of } \\
\text { discharge } \\
\text { valve }(\mathrm{L} / \mathrm{s})\end{array}$ & $\begin{array}{c}\text { Head on } \\
\text { section } \\
(\mathrm{m})\end{array}$ & $\begin{array}{c}Q \text { analytically } \\
\text { obtained } \\
(\mathrm{L} / \mathrm{s})\end{array}$ & $\begin{array}{c}\text { Difference } \\
(\%)\end{array}$ \\
\hline 1 & 1,000 & 0 & - & - & - \\
2 & 1,100 & 51.3 & 0.20 & 84.0 & -63.8 \\
3 & 1,200 & 198.7 & 1.05 & 192.5 & 3.1 \\
4 & 1,300 & 195.9 & 1.08 & 195.2 & 0.3 \\
5 & 1,400 & 200.4 & 1.07 & 194.3 & 3.0 \\
6 & 1,500 & 201.6 & 1.15 & 201.5 & 0.1 \\
\hline
\end{tabular}


Table 5. Flow rates obtained analytically versus model-derived flow rates in section (d) (weir)

\begin{tabular}{lccccc}
\hline Case & $\begin{array}{c}\text { Input flow } \\
\text { rate }(\mathrm{L} / \mathrm{s})\end{array}$ & $\begin{array}{c}Q \text { of } \\
\text { central } \\
\text { weir }(\mathrm{L} / \mathrm{s})\end{array}$ & $\begin{array}{c}\text { Head on } \\
\text { central } \\
\text { weir }(\mathrm{m})\end{array}$ & $\begin{array}{c}Q \text { analytically } \\
\text { obtained } \\
(\mathrm{L} / \mathrm{s})\end{array}$ & $\begin{array}{c}\text { Difference } \\
(\%)\end{array}$ \\
\hline 1 & 1,000 & 740 & 0.224 & 713.8 & 3.54 \\
2 & 1,100 & 771 & 0.231 & 747.5 & 3.05 \\
3 & 1,200 & 803 & 0.238 & 781.7 & 2.65 \\
4 & 1,300 & 906 & 0.257 & 877.2 & 3.18 \\
5 & 1,400 & 981 & 0.278 & 986.9 & -0.60 \\
6 & 1,500 & 1,070 & 0.290 & $1,051.5$ & 1.73 \\
\hline
\end{tabular}

account because the valve was only partially actuated, which means that it was a variable regime with different partial openings, and, subsequently, the analytical results cannot be considered valid. For Cases 3, 4, 5, and 6, a match was obtained between the numerical solution from simulations and the analytical solution, with a maximum error of $3.1 \%$ (Case 3 ).

Table 5 compares values obtained from the numerical simulation with those obtained analytically from Eq. (2) for the flow on the wire, $Q(a)$. There was adequate correspondence between them, with a maximum variability of $3.54 \%$ (Case 1 ).

\section{Conclusions}

The numerical model of the hydrometric module was found to have good consistency and to comply with the von Neumann stability analysis and is, therefore, a convergent model. The model was validated by comparing the analytical results of a physical problem with the results of the numerical model itself, presenting a strong correlation.

The behavior of the hydrometric module with the designed dimensions reduced the inflow so that the limit value of $1,000 \mathrm{~L} / \mathrm{s}$ was not exceeded. This was at the expense of discharging a variable flow rate through the sluice gate of the regulating manhole together with an additional flow rate through the discharge valve.

A prerequisite for this, i.e., automatic overflow control regulated by discharge, was precise positioning of the sluice gate in the first manhole, because a slight change had a significant impact on the volume of water that crosses it. For arrival flows of less than $1,200 \mathrm{~L} / \mathrm{s}$, considerable flow was wasted through the sluice gate; manual shut-off would have been necessary to avoid this. On the other hand, for flow rates of more than $1,500 \mathrm{~L} / \mathrm{s}$, the discharge valve capacity was limited to discharging a maximum of $200 \mathrm{~L} / \mathrm{s}$, an amount that was insufficient, and therefore should have been increased to obtain a greater regulating capacity. However, these very high flows probably did not reach the hydrometric module because upstream, immediately after the river catchment, spill occurred through lateral weir gates. Therefore, it can be deduced that the hydrometric module fulfilled its function within the flow rate range and, despite having an automated regulation system, the correct adjustment of the slide gate position would have required human supervision to avoid misuse of the spilled flow rates.

This case study shows the benefits of numerical calculation, especially when real situations are difficult to measure. CFD allowed detailed insight into flow evolution over time, which is important for understanding the problem dynamic behavior and its response to changes, as well as the mechanism response that interacts with the fluid. For future research, more computing power would facilitate conducting more simulations and determining the hysteresis of this mechanism with the aim to further explore the behavior of the hydrometric module and, especially, its limitations.

\section{Acknowledgments}

This work was partially supported by the Spanish government (Project Nos. DPI2013-40882-P and DPI2016-80077-R). Conflict of Interest-None.

\section{Notation}

The following symbols are used in this paper:

$A_{h}=$ surface area of orifice;

$C_{d}=$ discharge coefficient for rectangular weir;

$e=$ specific enthalpy;

$g=$ acceleration due to gravity;

$H=$ head above orifice;

$h=$ head over weir;

$k_{d}=$ discharge coefficient of orifice;

$p=$ pressure;

$Q=$ flow rate;

$S_{h}=$ enthalpic source;

$T=$ temperature;

$t=$ time;

$\mathbf{u}=$ velocity of flow in $x$-direction;

$\mathbf{v}=$ velocity of flow in $y$-direction;

$v_{\text {fluid }}=$ average speed module;

$\nabla=$ gradient;

$\Delta t=$ time step;

$\Delta x=$ cell size; and

$\rho=$ density.

\section{Supplemental Data}

Video S1 and the models for Cases 1-6 are available online in the ASCE Library (www.ascelibrary.org).

\section{References}

Ali, Z., P. G. Tucker, and S. Shahpar. 2017. "Optimal mesh topology generation for CFD." Comput. Methods Appl. Mech. Eng. 317 (Apr): 431-457. https://doi.org/10.1016/j.cma.2016.12.001.

Andersson, A. G., P. Andreasson, and T. Staffan Lundström. 2013. "CFDmodelling and validation of free surface flow during spilling of reservoir in down-scale model." Eng. Appl. Comput. Fluid Mech. 7 (1): 159-167. https://doi.org/10.1080/19942060.2013.11015461.

Arvanaghi, H., and N. N. Oskuei. 2013. "Sharp-crested weir discharge coefficient." J. Civ. Eng. Urbanism 3 (3): 87-91.

Aydin, I., A. B. Altan-Sakarya, and C. Sisman. 2011. "Discharge formula for rectangular sharp-crested weirs." Flow Meas. Instrum. 22 (2): 144-151. https://doi.org/10.1016/j.flowmeasinst.2011.01.003.

Aydin, M. C. 2016. "Investigation of a sill effect on rectangular side-weir flow by using CFD.” J. Irrig. Drain. Eng. 142 (2): 04015043. https://doi .org/10.1061/(ASCE)IR.1943-4774.0000957.

Babaali, H., A. Shamsai, and H. Vosoughifar. 2015. "Computational modeling of the hydraulic jump in the stilling basin with convergence walls using CFD codes." Arabian J. Sci. Eng. 40 (2): 381-395. https://doi.org /10.1007/s13369-014-1466-z.

Bhajantri, M. R., T. I. Eldho, and P. B. Deolalikar. 2006. "Hydrodynamic modelling of flow over a spillway using a two-dimensional finite volume-based numerical model." Sadhana 31 (6): 743-754. https://doi .org/10.1007/BF02716893.

Blasone, M., F. Dell'Anno, R. De Luca, O. Faella, O. Fiore, and A. Saggese. 2015. "Discharge time of a cylindrical leaking bucket." Eur. J. Phys. 36 (3): 035017. https://doi.org/10.1088/0143-0807/36/3 1035017. 
Franchini, M., and L. Lanza. 2013. "Leakages in pipes: Generalizing Torricelli's equation to deal with different elastic materials, diameters and orifice shape and dimensions." Urban Water J. 11 (8): 678-695. https://doi.org/10.1080/1573062X.2013.868496.

Hargreaves, D. M., H. P. Morvan, and N. G. Wright. 2007. "Validation of the volume of fluid method for free surface calculation: The broadcrested weir." Eng. Appl. Comput. Fluid Mech. 1 (2): 136-146. https:// doi.org/10.1080/19942060.2007.11015188.

Kirchner, H., J. Oliver, and S. Vela. 2002. Aigua prohibida: Arqueologia hidràulica del feudalisme a la Cerdanya: El Canal Reial de Puigcerdà. Bellaterra, Spain: Universitat Autònoma de Barcelona.

Latorre, X. 1995. Història de l'aigua a Catalunya. L'abecedari S.L. Barcelona: Barcelona, Spain.

Latorre, X. 2002. La Sèquia de Manresa. Girona, Spain: Fundació Pere García Fària.

Lin, C. H., J. F. Yen, and C. T. Tsai. 2002. "Influence of sluice gate contraction coefficient on distinguishing condition." J. Irrig. Drain. Eng. 128 (4): 249-252. https://doi.org/10.1061/(ASCE)0733-9437(2002) 128:4(249).

Namaee, M. R., M. Rostami, S. Jalaledini, and M. Habibi. 2014. "A 3D numerical simulation of flow over a broad-crested side weir." In Advances in hydroinformatics, 511-523. Dordrecht, Netherlands: Springer.

Namaee, M. R., and R. Shadpoorian. 2016. "Numerical modeling of flow over two side weirs." Arabian J. Sci. Eng. 41 (4): 1495-1510. https://doi .org/10.1007/s13369-015-1961-x.

Oliveras, J. 1986. La consolidació de la ciutat industrial: Manresa (1871-1900). Manresa, Spain: Caixa d'Estalvis de Manresa.
Pandeyp, R., P. K. Mittalp, and P. M. K. Choudharyp. 2016. "Flow characteristics of sharp crested rectangular weir: A review." Int. J. Innovate Sci. Eng. Technol. 3 (3): 171-178.

Sarkardeh, H., A. Reza Zarrati, E. Jabbari, and M. Marosi. 2014. "Numerical simulation and analysis of flow in a reservoir in presence of vortex." Eng. Appl. Comput. Fluid Mech. 8 (4): 598-608. https://doi.org/10 .1080/19942060.2014.11083310.

Sarret, J. 1906. La Cequia de Manresa. Manresa, Spain: Caixa d'Estalvis de Manresa.

Taghavi, M., and H. Ghodousi. 2015. "Simulation of flow suspended load in weirs by using FLOW-3D model." Civ. Eng. J. 1 (1): 37-49.

Turalina, D., D. Yembergenova, and K. Alibayeva. 2015. "The experimental study of the features of water flowing through a sharp-crested weir in channel." In Vol. 92 of Proc., EPJ Web of Conf., 1-5. Les Ulis, France: EDP Sciences.

Verstappen, R., and A. Veldman. 2003. "Symmetry-preserving discretization of turbulent flow." J. Comput. Phys. 187 (1): 343-368. https://doi .org/10.1016/S0021-9991(03)00126-8.

Versteeg, H. K. H. K., and W. W. Malalasekera. 2007. An introduction to computational fluid dynamics: The finite volume method. Harlow, UK: Pearson.

White, F. M. 1999. Fluid mechanics. Boston: McGraw-Hill.

Wu, S., and N. Rajaratnam. 2015. "Solutions to rectangular sluice gate flow problems.” J. Irrig. Drain. Eng. 141 (12): 06015003. https://doi.org/10 .1061/(ASCE)IR.1943-4774.0000922.

Zeng, J., L. Zhang, M. Ansar, E. Damisse, and J. A. González-Castro. 2017. "Applications of computational fluid dynamics to flow ratings at prototype spillways and weirs. I: Data generation and validation." J. Irrig. Drain. Eng. 143 (1): 04016072. https://doi.org/10.1061/(ASCE)IR .1943-4774.0001112. 